\title{
Library Diversity and Residency Studies
}

Volume 1 | Issue 1

Article 6

$4-22-2020$

Planning an LDR

Gerald Holmes

Follow this and additional works at: https://digitalcommons.Isu.edu/ldrs

Part of the Library and Information Science Commons

\section{Recommended Citation}

Holmes, Gerald. "Planning an LDR." Library Diversity and Residency Studies 1, 1 (2020): 29-32. doi:10.31390/ldrs.1.1.06. 


\title{
Planning a Library Diversity Residency Program
}

\author{
Strategies for Diversity Coordinators to Build Support for their Programs
}

\author{
Gerald Holmes
}

The essence of most Library Diversity Residency programs is to foster an early career librarians' professional growth while investing in the libraries' commitment to equity, diversity and inclusion. Recruiting and retaining librarians for future positions in various types of libraries is both critical and challenging in today's environment. It is imperative that we recognize the demographic and cultural changes in the communities that we serve, and promote diversity by recruiting, mentoring, and providing professional opportunities to diverse early career librarians.

This article provides recommendations and strategies for those seeking to either establish or strengthen a Library Diversity Residency program. As the coordinator of a residency program, it is vital to widely discuss and share information about the program with other library personnel. It is important that you understand the work that must occur before the search committee begins their work to hire the resident.

Building support is a part of the daily work of maintaining a forward-thinking Library Diversity Residency program. The University of Tennessee's program states "the Libraries' expectation for the program is that it will bring into our organization not only ethnic and cultural diversity but also the fresh enthusiasm and skills of recent library and information science graduates." (Mack and Keally 2004)

\section{BUILDING BROAD FOUNDATION AND SUPPORT FOR THE PROGRAM}

There are several key groups which typically must be convened and engaged in planning to build broad support for the program, as follows.

\section{Residency Planning Committee}

The Residency Planning Committee (RPC) is a short-term taskforce not a permanent committee. The taskforce has one action item to complete. It is to meet and explore ideas to create a planning document for the residency program. The RPC will survey and host all-staff library forums to collect input from library staff and librarians.

The RPC will develop an outline for the content of the residency planning report. The planning report will identify and recommend learning opportunities and events (especially Equity, Diversity and Inclusion) at the university library for library staff and librarians. The RPC will review and update the library diversity web page, diversity blog and other communication outlets. The RPC will assist in the collection of campus data and library data to justify and support the creation of a Library Diversity Residency program. The RPC will have a committee charge to explore, create, set the goals and objectives, the timeline for the program, decide how to evaluate the program, monitor the residency program including evaluations, assessments, and reports.

The dean or director of the library will appoint the RPC. The membership of the RPC may include the following members:

- Residency Coordinator (Committee Chair)

- Several representatives from the library staff and librarians

- Department of Library and Information Science Faculty (if the university has an LIS program) 
- A representative from relevant university diversity-related offices (such as the Equal Employment Office, the Office of Intercultural Engagement, etc.)

\section{Residency Advisory Committee}

The RPC and the director will appoint the Residency Advisory Committee (RAC). Initial steps to building support for the Library Diversity Residency program begin with planning and brainstorming. Creating a RAC is the first step in seeking buy-in for this major commitment. The RAC must have the mission and committee charge of exploring the different types of residency programs in order to submit a proposal to the director of what that library wants to accomplish with their residency program. At UNC Greensboro, our goal is to help attract a diverse pool of candidates for all library positions, especially the diversity residency position. The RAC should be a permanent committee charged to explore, create, invite members to serve on the RPC, monitor the residency program (including evaluations, assessments, and reports). The committee will monitor and set the goals and objectives, monitor the timeline for the program, assist in evaluating the program, making recommendations accordingly to the dean or director about the residency program.

The RAC will explore and consider connections between the residency program and other related diversity initiatives. For example, providing recommendations for training and facilitating professional development for library staff and librarians is a key role for the RAC. Other initiatives for the RAC might include preparation for diversifying the staffing in the library and creating a welcoming environment which involves Equity, Diversity and Inclusion (EDI) training. Other important tasks for the RAC include monitoring and participating in revising and updating the library diversity web page, diversity blog, and other communication outlets highlighting EDI efforts on campus. The RAC can assist in the collection of campus data and library data that can be used in creating benchmarks to measure EDI on campus, and compare that data with peer institutions. Community based thinking will also help the program remain grounded in community engagement efforts.

Membership of the Residency Advisory Committee may include a combination of the following:

- A senior library administrative services official or human resources official, as appropriate

- The residency coordinator

- Department of Library and Information Science Faculty (if the university has an LIS program)

- A representative from a regional public library

- A representative from relevant university diversity-related offices (such as the Equal Employment Office, the Office of Intercultural Engagement, etc.)

- A representative from other relevant campus groups with a focus on EDI

\section{University Administration}

Building support for the Library Diversity Residency program with university administrative officials (such as the Provost, senior vice-president for academic affairs, or similar campus position) is important. University administrators should participate in the effort to improve the pipeline of diverse individuals who will become librarians. The library dean or director should approach other university administrators for their suggestions and ideas in increasing the diversity of the pool of applicants for librarian positions. The library dean or director will have an opportunity to introduce newly hired residents to members of the university administration.

\section{BUILDING AND SUSTAINING SUPPORT FOR THE Program among Colleagues}

There are several important stakeholders that coordinators should take steps to engage in the process. 


\section{Senior Library Administration Officials}

Building support for the residency program is a priority for members of the library administrative team. A senior member of the library administration should monitor all aspects of the residency program, and periodically make recommendations. They should assist the residency coordinator in facilitating learning opportunities and events for the resident. Approving travel funding to appropriate conferences and workshops for the resident, as well as librarians and library staff who will work closely with the resident, will strengthen the residency program. If the ACRL Diversity Alliance institutes continue in the future, it will be extremely important for the library administration to fund the resident to attend such institutes. The administration and everyone else involved with the residency program should periodically remind themselves that the primary objective of the residency program is to prepare the early career librarian for a successful career.

\section{Librarians and Library Staff}

Both librarians and library staff from all parts of the organization should take responsibility for building support for the residency program, including participation in the development and implementation of the residency program. Librarians and library staff should also take responsibility for continuing growth and education in EDI principles and practices, taking advantage of events, programs, workshops, and webinars for their personal professional development. All library departments should contribute a portfolio of ideas to the residency program regarding their departmental activities, including ideas for projects that a resident may be assigned, projects that have been completed by former residents, information about work in the department, information on relevant library careers, and departmental goals related to the library's strategic plan. To facilitate learning about the duties and responsibilities of all library departments, the resident should be invited to spend a day in all departments, whether or not the resident will serve a rotation in the department.
The visit could include a tour of the department, introductions to staff, and the opportunity to sit in on departmental meetings and special events. When new librarians and library staff are hired, there should be an opportunity to orient them to the residency program and all diversity initiatives in the library. This may be an opportune time to invite their support and ideas for advancing library diversity initiatives.

\section{The Resident}

The resident should document their activities effectively. Assessment and evaluation should demonstrate how a resident's knowledge base and skill set was improved to help prepare them for future professional librarian positions. The resident will be called upon to represent the library at workshops, conferences, career fairs, programs, presentations, and other outreach opportunities. The resident should participate in facilitating learning opportunities and events for librarians and library staff. Maintaining and updating the library diversity web presence can demonstrate the resident's contribution to the mission of the library. The resident should maintain a log of activities and projects related to their residency work. They should update their resume and curriculum vitae, regularly. Building support also entails making recommendations to the library on ways to improve outreach efforts, instruction methods, collection development, and resource access in order for the library to meet the needs of patrons of diverse populations and backgrounds.

\section{Residency Program Coordinator}

The residency program coordinator has a central role in the program. Part of the role of the residency coordinator is to oversee assessment and evaluation of the residency program in collaboration with the RAC. The coordinator will meet regularly with the resident to monitor his or her progress and to encourage the resident to explore new ideas related to their personal interests and growth. The coordinator should look forward to introducing the resident as an early career professional to the library profession. The coordinator should promote librarianship as 
a career valuable to a diverse population. The coordinator should make suggestions and recommendations concerning the resident's participation in onboarding and program orientation to work in the library. The coordinator will be called upon to represent the residency program at library administrative group meetings. Brewer succinctly states that, "Program Coordinators must take care to identify supervisors who are genuinely interested in working with new librarians. This means being available and inclusive as developmental opportunities arise.” (Brewer 2001)

The residency program coordinator will participate in monitoring and updating the library diversity web page, blogs, and related communication outlets. Depending on the resident's areas of special interest, the coordinator should encourage the resident to visit one or two other academic libraries nearby or within the region. This visit should include a library tour, staff introductions, and time to visit with staff working within areas of interest to the resident. Such visits allow the resident to become familiar with other academic libraries, and how they treat areas of special interest. Visits also raise the visibility of the residency program in the region. The coordinator should organize a residency recognition program at the conclusion of the residency. The coordinator should involve the resident in planning the event as well. It may be appropriate to present an award, or item of significance to the resident at this point.

The coordinator should work with library staff responsible for public relations or marketing in order to publicize the residency program. Press releases could be distributed about the resident when they begin work. Press releases may be sent to library and campus news outlets, as well as selected other publications as appropriate. This can help to promote the residency program and build support for the program.

\section{Conclusion}

Building support for the residency program begins long before the work of the hiring process by the search committee. Establishing goals and objectives, identifying diversity initiatives to build the program are key for the success of the program. It is important that administrators, librarians, and library staff work to advance the progress of the resident and the success of the residency program. It is important to answer the question, "Why does this residency program make a difference?" Residency programs seek to encourage early career progress and foster collegiality. Planning and hosting Library Diversity Residency programs makes a difference by preparing residents for career paths of their choice, and is critical to cultivating the profession of librarianship.

\section{REFERENCES CITED}

Mack, T. \& Jill Keally. 2004. "Seeding the vision: designing a minority librarian residency program", The Southeastern Librarian, 52(1), 5-9.

Brewer, T. 2001. "Reflections of an academic library residency program coordinator," in Cogell, R. V.\& Gruwell, C. A. (Eds.). Diversity in Libraries - Academic Residency Programs. Westport, Conn.: Greenwood Press. 